\title{
ANALISIS PREFERENSI KONSUMEN TERHADAP PRODUK OLAHAN MANGGA
}

\section{ANALYSIS OF CONSUMER PREFERENCES FOR PROCESSED MANGO PRODUCTS}

\author{
Nurisa Asrienda Shafira ${ }^{1 *}$, Elly Rasmikayati², Bobby Rachmat Saefudin ${ }^{3}$ \\ ${ }^{12}$ Fakultas Pertanian, Universitas Padjadjaran \\ ${ }^{3}$ Fakultas Pertanian, Ma'soem University \\ *E-mail: nurisa.shafira@gmail.com \\ (Diterima 02-02-2021; Disetujui 03-06-2021)
}

\begin{abstract}
ABSTRAK
Produksi mangga di Indonesia yang bersifat musiman menyebabkan hasil produksi mangga menjadi melimpah pada saat musim panen dan langka ketika di luar musim panen. Saat ini, telah banyak alternatif dalam pengolahan mangga menjadi produk olahan agar konsumen dapat tetap mengonsumsi mangga di luar musim panen. Namun, belum diketahui produk olahan mangga seperti apa yang sesuai dengan preferensi konsumen. Penelitian ini bertujuan untuk mendeskripsikan karakteristik konsumen produk olahan mangga serta menganalisis preferensi konsumen terhadap produk olahan mangga. Metode yang digunakan dalam penelitian ini adalah statistik deskriptif dan analisis conjoint. Hasil penelitian menunjukkan bahwa konsumen produk olahan mangga didominasi oleh perempuan yang berusia 21 tahun dengan uang saku Rp500.000 Rp1.000.000 per bulan dan bertempat tinggal di daerah Jawa. Preferensi konsumen terhadap produk olahan mangga mengacu pada pilihan produk puree mangga dengan rasa masam dan harga yang rendah (kurang dari Rp15.000). Urutan atribut produk yang penting bagi konsumen yaitu harga $(46 \%)$, jenis produk $(41 \%)$, dan rasa $(13 \%)$.
\end{abstract}

Kata kunci: Karakteristik, Preferensi Konsumen, Produk Olahan Mangga, Analisis Conjoint

\begin{abstract}
The production of mangoes in Indonesia, which is seasonal, causes mango production to be abundant during the harvest season and scarce when it is outside the harvest season. Currently, there are many alternatives in processing mangoes into processed products so that consumers can continue to consume mangoes outside the harvest season. However, it is not known what kind of mango processed products that are suitable for consumer preferences. This study aims to describe the characteristics of consumers of mango processed products and consumer preferences for processed mango products. The method used in this research is descriptive statistics and conjoint analysis. The results showed that consumers of processed mango products were dominated by women aged 21 years with an allowance of IDR 500.000 - IDR 1,000,000 per month and live in Java. Consumer preference for processed mango products refers to the choice of mango puree products with a sour taste and low price (less than IDR 15,000) The order of product attributes that are important to consumers is price (46\%), type of product (41\%), and taste (13\%).
\end{abstract}

Keywords : Characteristics, Preferences, Processed Mango Products, Conjoint Analysis

\section{PENDAHULUAN}

Mangga merupakan tanaman hortikultura yang cukup penting baik untuk pasar domestik maupun pasar ekspor. Berdasarkan data FAO (2019), komoditas mangga merupakan komoditas 
dengan pertumbuhan tercepat di antara buah-buahan tropis utama pada tahun 2019. Peningkatan ekspor mangga global tersebut dapat terjadi karena produksi mangga di dunia yang juga mengalami peningkatan. Berdasarkan data FAOSTAT (2019), produksi mangga di dunia pada tahun 2014 hingga tahun 2018 terus mengalami peningkatan dengan rata-rata sebesar 3,8\% setiap tahunnya. Produksi mangga ini dihasilkan oleh gabungan lebih dari produksi mangga di 100 negara baik negara tropis maupun negara subtropis. Meskipun begitu, sekitar 50 persen dari produksi mangga di dunia dihasilkan oleh lima negara dengan produksi mangga terbesar di dunia, yaitu India, China, Thailand, Indonesia, dan Pakistan

Data dari FAOSTAT (2019) menunjukkan bahwa Indonesia termasuk ke dalam lima negara produsen mangga terbesar di dunia pada tahun 2018 dengan peringkat produksi mangga terbesar keempat setelah India, China, dan Thailand dengan produksi sebesar 3.083.643 ton. Namun, produksi mangga di Indonesia bersifat musiman, yakni pada saat panen raya produksi mangga sangat melimpah, namun setelah musim berlalu mangga menjadi langka. Produksi mangga yang tidak stabil tersebut menyebabkan harga buah mangga menjadi tidak stabil. Diketahui musim panen mangga terjadi pada bulan Agustus hingga November. Berdasarkan hasil penelitian Wandschneider et al (2012), harga mangga umumnya tinggi antara Mei sampai pertengahan Juli, kemudian mengalami penurunan drastis ketika puncak produksi pada Agustus dan mengalami penurunan paling tajam yang terjadi pada Oktober dan November ketika pasar dibanjiri mangga. Pada November pertengahan sampai akhir, ketika panen mendekati habis, harga mulai merangkak naik kembali.

Berdasarkan data FAO (2018), sekitar 16 persen dari produksi mangga di India selaku produsen mangga terbesar di dunia diolah menjadi berbagai produk olahan karena sifat buah mangga yang mudah rusak dan sulit untuk disimpan. Selain dapat meningkatkan umur simpan, pengolahan mangga menjadi produk olahan juga dapat menghasilkan pendapatan yang berkelanjutan bagi produsen melalui penambahan nilai dan menciptakan akses yang lebih baik ke pasar. Pengelolaan komoditas mangga di India dapat dijadikan sebagai contoh bagi Indonesia untuk mengatasi permasalahan pada komoditas mangga di Indonesia yaitu harga mangga yang cenderung 
rendah terutama ketika panen raya sehingga menyebabkan rendahnya pendapatan petani mangga dan ketersediaan mangga yang tidak stabil akibat panen mangga yang bersifat musiman.

Merujuk pada data Badan Ketahanan Pangan (2019), konsumsi mangga masyarakat Indonesia terus mengalami peningkatan dari tahun 2013 hingga tahun 2017. Peningkatan konsumsi tersebut dapat memberi peluang untuk mengembangkan komoditas mangga di Indonesia. Meningkatnya konsumsi tersebut dapat menunjukkan bahwa mangga semakin digemari dan dicari-cari oleh masyarakat Indonesia dari tahun ke tahun. Maka dari itu produsen mangga dituntut untuk dapat memproduksi dan memasarkan produk dengan kualitas dan kuantitas yang dapat memuaskan kebutuhan konsumen baik dalam bentuk buah segar maupun produk olahan.

Berdasarkan penelitian yang dilakukan oleh Balai Besar Penelitian dan Pengembangan Pascapanen Pertanian (2010) mengenai berbagai jenis produk olahan mangga menyatakan bahwa terdapat beberapa produk olahan mangga yang telah diproduksi di Indonesia. Jenis produk olahan mangga tersebut meliputi puree mangga, selai mangga, dodol mangga, sirup mangga, manisan mangga, mangga kering, dan keripik mangga. Qoddhar dkk (2013) menyatakan bahwa konsumen produk olahan mangga mayoritas adalah laki-laki dengan usia 18 hingga 30 tahun. Mereka lebih mementingkan rasa, aroma, dan warna dari produk olahan mangga sebelum memutuskan untuk melakukan pembelian.

Dapat dilihat bahwa setiap konsumen memiliki kriteria yang berbeda baik dari karakteristik konsumennya sendiri maupun karakteristik produk yang diinginkan sesuai dengan preferensi mereka. Menurut Wartaka (2004), preferensi konsumen merupakan sesuatu yang diamati, suatu pilihan utama, dan merupakan kebutuhan prioritas bagi konsumen. Preferensi konsumen sangat penting dilakukan untuk membantu produsen merancang strategi pemasaran yang tepat untuk menarik konsumen dan juga dapat membantu produsen untuk melihat apakah atribut yang ditawarkan pada produk sudah memenuhi harapan konsumen atau belum. Produsen pun dapat membuat produk dengan melihat pilihan atribut yang disukai oleh konsumen atau mempertahankan atribut pilihan konsumen. 


\begin{abstract}
Dalam rangka mengetahui karakteristik konsumen yang suka mengonsumsi produk olahan mangga serta karakteristik produk olahan mangga yang disukai oleh konsumen, perlu dilakukan penelitian mengenai preferensi konsumen terhadap produk olahan mangga.
\end{abstract}

\section{METODE PENELITIAN}

Metode pengumpulan data yang digunakan dalam penelitian ini adalah metode survei pada mahasiswa Fakultas Pertanian Universitas Padjadjaran angkatan 2017-2020. Pemilihan tempat penelitian adalah secara sengaja dengan pertimbangan bahwa mahasiswa Fakultas Pertanian akan lebih paham mengenai permasalahan produksi mangga di Indonesia dan juga mengenai pengolahan mangga. Teknik pengambilan sampel dilakukan dengan cara simple random sampling dengan jumlah sampel 94 responden dari populasi sebanyak 1387 mahasiswa. Namun, dengan pertimbangan dapat terjadinya kesalahan dalam proses pengumpulan data, maka peneliti memutuskan untuk mengambil sampel sebanyak 114 responden. Proses pengumpulan data pada penelitian ini dilakukan pada bulan Oktober 2020Januari 2021.
Pengambilan data primer dalam penelitian ini dilakukan dengan membagikan kuesioner pada responden. Kuesioner terdiri atas dua bagian dengan bagian pertama berisi pertanyaan tentang karakteristik konsumen produk olahan mangga dan bagian kedua tentang preferensi konsumen terhadap produk olahan mangga. Bagian kedua diisi dengan memberikan nilai secara rating pada kombinasi-kombinasi produk yang tersedia dengan skala 1 sampai 5 untuk kombinasi produk yang paling tidak disukai sampai yang paling disukai.

Analisis karakteristik konsumen dilakukan menggunakan statistik deskriptif dimana menggambarkan ciri individu yang dapat mempengaruhi perilaku konsumen dalam melakukan pembelian terhadap suatu produk yaitu diantaranya: jenis kelamin, usia, tempat tinggal, dan uang saku.

Analisis preferensi konsumen dilakukan menggunakan analisis konjoin untuk mengidentifikasi kombinasi atribut produk olahan mangga yang paling disukai konsumen dan kepentingan relatif dari setiap atribut tersebut. Atribut yang dinilai menggunakan analisis konjoin meliputi jenis, rasa, dan harga untuk produk olahan mangga. Hasil analisis konjoin akan digunakan untuk mengukur 
nilai kegunaan dan nilai kepentingan dari tiap-tiap atribut tersebut.

\section{HASIL DAN PEMBAHASAN}

\section{Karakteristik Konsumen Produk}

\section{Olahan Mangga}

\subsection{Karakteristik}

Konsumen

\section{Berdasarkan Jenis Kelamin}

Hasil penelitian karakteristik konsumen yang dilihat berdasarkan jenis kelamin ini menunjukkan bahwa konsumen terdiri atas mahasiswa yang berjenis kelamin laki-laki dan perempuan dengan proporsi seperti tampak pada diagram di bawah ini.

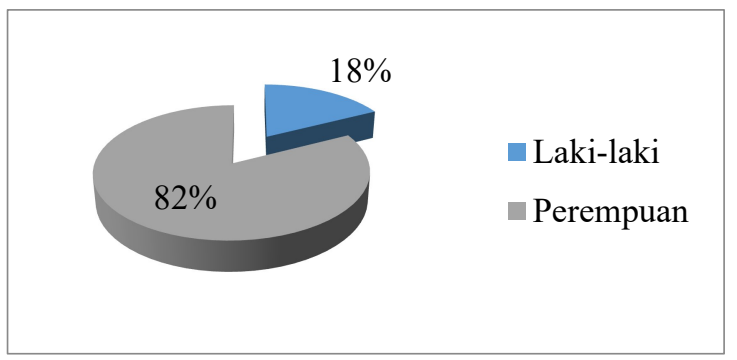

Gambar 1. Karakteristik Konsumen Berdasarkan Jenis Kelamin

Berdasarkan diagram di atas dapat dilihat bahwa konsumen produk olahan mangga terdiri atas mahasiswa yang berjenis kelamin perempuan dengan persentase $82 \%$ atau berjumlah 94 orang dan laki-laki dengan persentase $18 \%$ atau berjumlah 20 orang. Responden didominasi oleh mahasiswa yang berjenis kelamin perempuan. Perempuan cenderung mempunyai pengetahuan gizi yang baik sehingga memilih produk dengan gizi baik untuk dikonsumsi. Hasil penelitian ini mendukung penelitian Rachman dkk. (2017) yang menyatakan bahwa perempuan memiliki sikap yang lebih baik terhadap konsumsi buah dan sayur dibandingkan dengan laki-laki karena lebih mengetahui gizi yang dikandung dalam buah dan sayur. Ditambahkan oleh Rasmikayati dkk. (2021) bahwa kebanyakan konsumen perempuan memiliki preferensi tinggi terhadap suatu produk berdasarkan kualitas dan harga produk yang dibeli.

\subsection{Karakteristik Konsumen \\ Berdasarkan Usia}

Hasil penelitian karakteristik konsumen yang dilihat berdasarkan usia ini menunjukkan bahwa konsumen terdiri atas mahasiswa yang berusia 18 hingga 24 tahun dengan proporsi seperti tampak pada diagram di bawah ini.



\section{Gambar 2. Karakteristik Konsumen Berdasarkan Usia}

Berdasarkan diagram di atas dapat dilihat bahwa konsumen produk olahan mangga terdiri atas mahasiswa berusia 18 tahun dengan persentase $7 \%$ atau 
berjumlah 8 orang, 19 tahun dengan persentase $9 \%$ atau berjumlah 10 orang, 20 tahun dengan persentase $26 \%$ atau berjumlah 30 orang, 21 tahun dengan persentase $45 \%$ atau berjumlah 51 orang, 22 tahun dengan persentase $10 \%$ atau berjumlah 11 orang, 23 tahun dengan persentase $2 \%$ atau berjumlah 3 orang, dan 24 tahun dengan persentase $1 \%$ atau berjumlah 1 orang. Usia responden yang mendominasi pada penelitian ini adalah mahasiswa dengan usia 21 tahun.

Hasil penelitian ini memiliki kesamaan dengan penelitian Octaviani dkk. (2014) di Bandar Lampung mengenai produk olahan buah yang menyatakan bahwa konsumen produk olahan buah berupa jus mangga dan jus alpukat didominasi oleh perempuan dengan usia 21 tahun. Penelitian Sulistyawati dkk (2020) mengenai preferensi konsumen terhadap dried mango dengan responden konsumen dari Indonesia, China, dan Belanda juga menyatakan bahwa konsumen didominasi oleh perempuan dengan usia 18 hingga 25 tahun. Hasil tersebut menunjukkan bahwa konsumen produk olahan mangga di berbagai lokasi memiliki kemiripan yaitu konsumen mayoritas remaja dengan rentang usia 18 hingga 25 tahun.

\subsection{Karakteristik Konsumen \\ Berdasarkan Tempat Tinggal}

Hasil penelitian karakteristik konsumen yang dilihat berdasarkan tempat tinggal ini menunjukkan bahwa konsumen terdiri atas mahasiswa yang bertempat tinggal di Jawa dan luar Jawa dengan proporsi seperti tampak pada diagram di bawah ini.

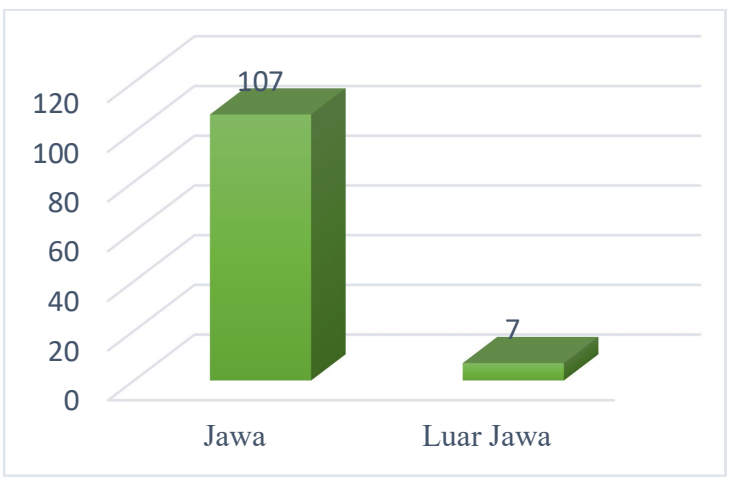

Gambar 3. Karakteristik Konsumen Berdasarkan Tempat Tinggal

Berdasarkan diagram di atas dapat dilihat bahwa konsumen produk olahan mangga terdiri atas mahasiswa yang bertempat tinggal di Jawa berjumlah 107 orang dengan persentase $94 \%$ dan luar Jawa berjumlah 7 orang dengan persentase $6 \%$. Responden didominasi oleh mahasiswa yang bertempat tinggal di daerah Jawa. Dominasi tempat tinggal ini berkaitan dengan daerah Jawa (Jawa Barat, Jawa Timur, dan Jawa Tengah) yang termasuk ke dalam daerah sentra mangga terbesar di Indonesia. Responden yang bertempat tinggal di daerah Jawa memiliki peluang yang lebih besar untuk 
mengonsumsi mangga baik dalam bentuk segar maupun produk olahan mangga.

Hasil penelitian ini memiliki kemiripan dengan penelitian Aeni (2017) di Malang tentang produk olahan buah berupa keripik buah yang menyatakan bahwa konsumen keripik buah didominasi oleh konsumen yang berasal dari daerah Malang selaku daerah penghasil keripik buah. Konsumen berpendapat bahwa produk lebih mudah dicari pada daerah penghasilnya dibandingkan pada daerah yang lain.

\subsection{Karakteristik}

Konsumen

\section{Berdasarkan Uang Saku}

Besar kecilnya pendapatan seseorang akan berpengaruh pada daya beli konsumen terhadap suatu produk. Semakin tinggi pendapatan maka semakin besar juga daya beli konsumen. Pada penelitian ini pendapatan mahasiswa dilihat berdasarkan uang saku per bulan yang dikategorikan dalam 3 kelompok. Hasil penelitian karakteristik konsumen yang dilihat berdasarkan uang saku ini menunjukkan bahwa konsumen terdiri atas mahasiswa yang memiliki uang saku di bawah Rp500.000, Rp500.000 - Rp1.000.000, dan lebih dari Rp1.000.000 dengan proporsi seperti tampak pada Tabel 1.
Tabel 1. Karakteristik Konsumen Berdasarkan Uang Saku

\begin{tabular}{|c|c|c|c|}
\hline No. & Uang Saku & $\begin{array}{l}\text { Jumlah } \\
\text { (Orang) }\end{array}$ & Persentase \\
\hline 1 & $<\operatorname{Rp500.000}$ & 16 & $14 \%$ \\
\hline 2 & $\begin{array}{l}\text { Rp500.000- } \\
\text { Rp1.000.000 }\end{array}$ & 51 & $45 \%$ \\
\hline 3 & $>$ Rp1.000.000 & 47 & $41 \%$ \\
\hline
\end{tabular}

Berdasarkan Tabel 1 dapat dilihat bahwa konsumen produk olahan mangga terdiri atas mahasiswa yang memiliki uang saku kurang dari Rp500.000 per bulan berjumlah 17 orang dengan persentase $14 \%, \quad \mathrm{Rp} 500.000 \quad-$ Rp1.000.000 per bulan berjumlah 51 orang dengan persentase $45 \%$, dan lebih dari Rp1.000.000 berjumlah 47 orang dengan persentase $41 \%$. Konsumen produk olahan mangga didominasi oleh mahasiswa yang memiliki uang saku pada kategori sedang yaitu Rp500.000 Rp1.000.000 per bulan.

Uang saku yang dimiliki oleh konsumen dapat mempengaruhi keputusan konsumen untuk melakukan pembelian pada suatu produk. Terdapat beberapa faktor yang diperhatikan oleh konsumen ketika akan memilih suatu produk diantaranya kualitas dan harga dari produk tersebut. Konsumen mengatakan bahwa mereka memprioritaskan harga produk sebelum memilih suatu produk disebabkan oleh uang saku yang terbatas dengan 
kebutuhan yang banyak. Mereka cenderung memilih produk berdasarkan kebutuhan yang paling dibutuhkan terlebih dahulu.

\section{Preferensi Konsumen Terhadap}

\section{Produk Olahan Mangga}

Penelitian ini memperoleh preferensi konsumen terhadap produk olahan mangga dengan menggunakan tiga atribut yaitu atribut jenis produk dengan subatribut (puree mangga, dodol mangga, dan selai mangga), atribut rasa dengan subatribut (manis dan masam), dan atribut harga dengan subatribut (rendah: < Rp15.000, sedang: Rp15.000 Rp20.000, tinggi: > Rp20.000). Preferensi konsumen terhadap produk olahan mangga dianalisis dengan menggunakan alat analisis konjoin untuk mengetahui tingkat kepentingan relatif dan nilai kegunaan dari atribut produk olahan mangga. Hasil analisis konjoin dapat dilihat pada Tabel 2 .

Tabel 2. Hasil Analisis Konjoin

\begin{tabular}{|c|c|c|c|c|}
\hline Atribut & $\begin{array}{c}\text { Nilai } \\
\text { Kepentingan }\end{array}$ & Taraf & $\begin{array}{c}\text { Nilai } \\
\text { Kegunaan }\end{array}$ & $\begin{array}{l}\text { Preferensi } \\
\text { Konsumen }\end{array}$ \\
\hline \multirow{3}{*}{$\begin{array}{l}\text { Jenis } \\
\text { produk }\end{array}$} & \multirow{3}{*}{41,159} & $\begin{array}{c}\text { Puree } \\
\text { mangga }\end{array}$ & 0,273 & \multirow{3}{*}{$\begin{array}{l}\text { Puree } \\
\text { mangga }\end{array}$} \\
\hline & & $\begin{array}{c}\text { Dodol } \\
\text { mangga }\end{array}$ & 0,080 & \\
\hline & & $\begin{array}{c}\text { Selai } \\
\text { mangga }\end{array}$ & $-0,353$ & \\
\hline \multirow{2}{*}{ Rasa } & \multirow{2}{*}{12,571} & & $-0,016$ & \multirow{2}{*}{ Masam } \\
\hline & & Masam & 0,016 & \\
\hline Harga & 46,270 & Rendah & 0,456 & Rendah \\
\hline
\end{tabular}

Sedang $\quad 0.080$

Tinggi $\quad-0,536$

Sumber : Hasil pengolahan dengan SPSS

Berdasarkan Tabel 2, dapat dilihat bahwa atribut yang paling penting bagi responden dalam membeli produk olahan mangga adalah atribut harga dengan nilai kepentingan yang paling besar yaitu $46 \%$, kemudian diikuti oleh atribut jenis produk dengan nilai kepentingan sebesar $41 \%$, dan terakhir adalah atribut rasa dengan nilai kepentingan sebesar 13\%. Atribut harga dan jenis produk memiliki nilai kepentingan yang tidak terlalu berbeda jauh sehingga produsen dalam memproduksi produk olahan mangga dapat mementingkan kedua hal tersebut. Hasil penelitian ini mendukung penelitian Widiyanto dkk. (2016) yang menyatakan bahwa atribut harga menjadi faktor pertama yang menjadi pertimbangan konsumen dalam memutuskan untuk melakukan suatu pembelian terhadap suatu produk. Sejalan dengan itu menurut Rasmikayati dkk. (2017), atribut rasa ini berkaitan dengan tingkat kepercayaan konsumen terhadap produk. Atribut harga dianggap penting karena konsumen memiliki daya beli yang berbeda-beda sehingga harus memperhatikan harga suatu produk sebelum memutuskan untuk melakukan pembelian. Natawidjaja dkk. 
(2017) mengungkapkan bahwa atribut harga berpengaruh pada willingness to pay dari konsumen terhadap suatu produk. Sari dkk. (2020) menyatakan bahwa konsumen bersedia membayar harga sekitar $10 \%$ lebih tinggi untuk produk yang berkualitas sesuai preferensi mereka.

Pilihan konsumen terhadap subatribut yang paling disukai dilihat berdasarkan nilai kegunaan. Menurut Rasmikayati dkk. (2020), nilai kegunaan menjadi salah satu faktor yang berpengaruh nyata terhadap kepuasan konsumen. Nilai kegunaan pada setiap subatribut dari atribut jenis produk menunjukkan bahwa konsumen lebih memilih produk olahan mangga berupa puree mangga dengan nilai kegunaan 0,273 . Hasil penelitian ini mendukung hasil penelitian Balai Besar Penelitian dan Pengembangan Pascapanen Pertanian (2010) yang menyatakan bahwa produk olahan mangga yang paling disukai konsumen adalah puree mangga. Puree mangga cenderung lebih disukai oleh konsumen karena merupakan produk olahan setengah jadi yang diolah dari buah mangga yang matang sempurna sehingga rasa buah mangga tetap kuat dan khas.
Pada atribut rasa, nilai kegunaan pada setiap subatributnya menunjukkan bahwa konsumen lebih memilih produk olahan mangga yang memiliki rasa masam dengan nilai kegunaan 0,016. Hasil penelitian ini mendukung hasil penelitian Widiyanto dkk. (2016) yang menyatakan bahwa rasa produk buah yang lebih disukai konsumen adalah rasa masam. Menurut konsumen, rasa produk olahan mangga yang masam tidak menjadi masalah asalkan produk sesuai dengan kebutuhan dan memiliki harga yang terjangkau. Hal tersebut sesuai dengan nilai kegunaan pada atribut harga yang menunjukkan bahwa konsumen lebih memilih produk olahan mangga yang harganya rendah yaitu kurang dari Rp15.000 dengan nilai kegunaan 0,456. Hal ini sejalan dengan hasil penelitian Saefudin dkk. (2020) yang menyimpulkan bahwa faktor leterjangkauan harga berpengaruh nyata dalam meningkatkan minat konsumen untuk membeli suatu produk. Ditambahkan lagi oleh Rasmikayati dkk. (2020) bahwa pemberian potongan harga dan promosi dapat menungkatkan penjualan suatu produk.

Untuk mengukur ketepatan hasil analisis konjoin yang telah dilakukan terhadap kombinasi atribut dengan hasil 
preferensi konsumen terhadap produk olahan mangga, dilakukan uji korelasi yang hasilnya dapat dilihat pada Tabel 3.

Tabel 3. Hasil Uji Korelasi

\begin{tabular}{ccc}
\hline Kriteria & Value & Sig. \\
\hline Pearson's R & 0,814 & 0,004 \\
Kendall's tau & 0,556 & 0,019 \\
\hline \multicolumn{2}{l}{ Sumber : Hasil pengolahan dengan SPSS }
\end{tabular}

Berdasarkan Tabel 3, dapat dilihat nilai korelasi Pearson's R sebesar 0,814 yang menunjukkan bahwa terdapat hubungan yang sangat kuat antara kombinasi atribut dengan preferensi konsumen terhadap produk olahan mangga yang ditandai juga dengan nilai signifikansi sebesar $0.004<0.05$. Hasil pengujian ini menunjukkan bahwa hasil analisis konjoin dapat diterima dalam menggambarkan preferensi konsumen terhadap produk olahan mangga. Penggunaan nilai korelasi Pearson's R disebabkan karena penelitian menggunakan cara rating dengan skala likert.

\section{KESIMPULAN DAN SARAN}

Berdasarkan hasil penelitian dan analisis yang telah dilakukan, dapat disimpulkan bahwa karakteristik konsumen produk olahan mangga secara umum didominasi oleh responden yang berjenis kelamin perempuan, berusia 21 tahun, bertempat tinggal di daerah Jawa, dan memiliki uang saku Rp500.000 Rp1.000.000 per bulannya.

Preferensi konsumen terhadap produk olahan mangga berdasarkan nilai kegunaan pada masing-masing subatribut mengacu pada pilihan produk puree mangga dengan rasa masam dan harga yang rendah $(<\mathrm{Rp} 15.000)$. Berdasarkan nilai kepentingan, urutan atribut produk yang paling penting bagi responden dalam membeli produk olahan mangga adalah atribut harga (46\%), jenis produk $(41 \%)$, dan rasa $(13 \%)$.

Berdasarkan hasil penelitian ini, diharapkan bagi produsen produk olahan mangga agar mempertimbangkan pilihan kombinasi produk olahan mangga berdasarkan preferensi konsumen yaitu puree mangga dengan rasa yang masam dan harga yang rendah $(<\mathrm{Rp} 15.000)$ atau mengutamakan atribut yang paling penting bagi konsumen yaitu harga sehingga dapat mempermudah pemasaran produk olahan mangga karena sesuai dengan selera konsumen.

\section{DAFTAR PUSTAKA}

[BKP]. Badan Ketahanan Pangan. (2019). Direktori Konsumsi Pangan 2019.

[FAO]. Food and Agriculture Organization. (2018). Food loss analysis: causes and solutions (Case study on the mango value chain in the Republic of India). 
[FAO]. Food and Agriculture Organization. (2019). Major Tropical Fruits Preliminary Market Results.

Aeni, Yayuk. (2017). Pengambilan Keputusan Konsumen dalam Pembelian Keripik Buah di Malang, Tesis, Universitas Hasanuddin.

Balai Besar Penelitian dan Pengembangan Pascapanen Pertanian. (2010). Difusi Teknologi Pengolahan Mangga (7 Produk Olahan) Kepada Kelompok Tani/Gapoktan dengan Target 2 Unit Usaha Berproduksi dan Dapat Meningkatkan Nilai Tambah Produk 50\%, Laporan Akhir Pelaksanaan Kegiatan Penelitian.

Natawidjaja, R. S., Sulistiowaty, L., Kusno, K., Aryani, D., \& Rachmat, B. (2017). Analisis Preferensi, Kepuasan, dan Kesediaan Konsumen Membayar Beras Di Kota Bandung.

Octaviani M. W, Yaktiworo Indriani, Suriaty Situmorang. (2014). Pengaruh Bauran Pemasaran (Marketing Mix) dan Perilaku Konsumen terhadap Pengambilan Keputusan Pembelian Jus Buah Segar Bandar Lampung, JIIA, Vol. 2, No. 2, hal. 133-141.

Qoddhar M. N, Panji Deoranto, Sakunda Anggarini. (2013). Studi Preferensi Konsumen terhadap Pasta Mangga Podang (Mangifera Indica L.) dengan Metode Conjoint (Studi Kasus Pada Hotel-Hotel Di Kota Batu), Jurnal Industria, Vol. 2, No. 1, hal. 17-26.

Rachman B. N, I Gede Mustika, I. G. A Wita Kusumawati. (2017). Faktor yang Berhubungan dengan Perilaku Konsumsi Buah dan Sayur Siswa SMP di Denpasar, Jurnal Gizi Indonesia Vol. 6, No. 1, hal. 9-16.
Rasmikayati, E., Deaniera, A. N., Supyandi, D., Sukayat, Y., \& Saefudin, B. R. (2020). Analisis Perilaku Konsumen: Pola Pembelian Kopi Serta Preferensi, Kepuasan Dan Loyalitas Konsumen Kedai Kopi Consumer Behavior: Purchase Pattern Of Coffee, Preferences, Satisfaction And Loyalty Of Coffee Shop Consumer. Mimbar Agribisnis: Jurnal Pemikiran Masyarakat Ilmiah Berwawasan Agribisnis. Juli, 6(2), 969-984.

Rasmikayati, E., Pardian, P., Hapsari, H., Ikhsan, R. M., \& Saefudin, B. R. (2017). Kajian Sikap dan Perilaku Konsumen dalam Pembelian Kopi Serta Pendapatnya Terhadap Varian Produk Dan Potensi Kedainya. Mimbar Agribisnis: Jurnal Pemikiran Masyarakat Ilmiah Berwawasan Agribisnis, 3(2), 117133.

Rasmikayati, E., Saefudin, B. R., Karyani, T., Kusno, K., \& Rizkiansyah, R. (2020). Analisis Faktor dan Tingkat Kepuasan Ditinjau dari Kualitas Produk dan Pelayanan pada Konsumen Sayuran Organik Di Lotte Mart Kota Bandung. Mimbar Agribisnis: Jurnal Pemikiran Masyarakat Ilmiah Berwawasan Agribisnis, 6(1), 351-364.

Rasmikayati, E., Syamsiah, S. T., Sadeli, A. H., \& Saefudin, B. R. (2021). Preferensi Konsumen Terhadap "Private Label" Ritel Modern Dikaitkan Dengan Karakteristik Konsumen: Studi Kasus Pada Produk Gula Di Lotte Mart Bandung. Mimbar Agribisnis: Jurnal Pemikiran Masyarakat Ilmiah Berwawasan Agribisnis, 7(1), 747-766.

Saefudin, B. R., Deanier, A. N., \& Rasmikayati, E. (2020). Kajian 
Pembandingan Preferensi

Konsumen pada Dua Kedai Kopi di Cibinong, Kabupaten Bogor. Agrovital: Jurnal Ilmu Pertanian, 5(1), 39-46.

Sari, Y., Rasmikayati, E., Saefudin, B. R., Karyani, T., \& Wiyono, S. N. (2020, March). Willingness To Pay Konsumen Beras Organik Dan Faktor-Faktor Yang Berkaitan Dengan Kesediaan Konsumen Untuk Membayar Lebih. In Forum Agribisnis (Vol. 10, No. 1, pp. 4657).

Sulistyawati I, Matthijs Dekker, Ruud Verkerk, Bea Steenbekkers. (2020). Consumer preference for dried mango attributes: A conjoint study among Dutch, Chinese, and Indonesian consumers, Journal of Food Science, Vol. 00, No. 0, pg.19.
Wandschneider T, Ian Baker, Ronnie Natawidjaja. (2012). Studi Rantai Nilai Mangga, Australian Centre for International Agricultural Research.

Wartaka, M. (2004). Analisa Preferensi Konsumen Produk Lipstik dan Kaitannya dengan Segmentasi Produk. Tesis. Universitas Budi Luhur Jakarta.

Widiyanto, N. A, Andriyono K. A, Heny K. Daryanto. (2016). AtributAtribut yang Mempengaruhi Sikap dan Preferensi Konsumen dalam Membeli Buah Apel di Kota Surabaya dan Kota Malang Provinsi Jawa Timur, Jurnal Ilmu Keluarga dan Konsumen Vol. 9, No. 2, hal. 136-146. 